\author{
Magdalena Fuhrmann \\ University of Warsaw \\ Faculty of Geography and Regional Studies \\ Department of Urban Geography and Spatial Organisation \\ e-mail: mfuhrmann@uw.edu.pl
}

\title{
RESIDENTS' RELATIONSHIP WITH THE TERRITORY AND THE SPATIAL PLANNING OF RESIDENTIAL HOUSING DEVELOPMENTS
}

\begin{abstract}
Residential housing developments built using the prefabricated method during the 1970s undoubtedly have their very own specificities. There exists a wide variety of opinions of the housing developments themselves, as well as of their social condition. The aim of this article is to identify residents' relationships with the residential housing development territory and to demonstrate the variety of those relationships as conditioned by various types of spatial planning. Various planning elements were taken in to account: building layout, green spaces, and recreational grounds. Residents' relationships with the territory are conveyed by individual residents' evaluations of their residential housing development (housing development evaluation, feelings of belonging) and external manifestations of attachment to the development (local involvement). The described topics are demonstrated using the examples of 4 residential housing developments in Warsaw.
\end{abstract}

Key words: relationship with territory, residential housing development, spatial planning in residential housing developments.

\section{RESIDENTIAL HOUSING DEVELOPMENT - DEFINITION}

Among architects, town planners, sociologists, and representatives of other disciplines concerned with what is broadly understood as the residential function of cities, there are ongoing discussions on the definition of residential housing development. Various interchangeable terms are in use, such as: large-scale residential complex or housing estate. This article follows Misiak's (1993) definition of residential housing developments as „complexly planned areas in designated on designated urban spaces, where residential functions dominate over others and where residential block buildings are most often constructed using industrial technologies". 


\section{RELATIONSHIPS WITH THE TERRITORY}

The present article's objects of interest are the spatial attributes of residential housing developments, which can be discerned by their form (buildings, spatial planning, size, aesthetics), function (role of the residential housing development space and its "offer" for residents), and their significance for residents. Residents' relationships with the territory may be characterised by:

- Individual evaluations of the residential housing development space (individual's relationship with various planning elements),

- Emotional attachment to the housing development,

- Residents' involvement in the housing development's affairs.

Individual evaluations of the housing development space may be represented as the degree of residents' satisfaction with the space that surrounds them. The evaluations included elements such as: the development's open space, adjacent recreational areas, green spaces, and development size (number and size of buildings, development surface area). Residents' emotional attachment to the development may be described in direct and indirect terms. In the first case, it is the emotional attachment to the development, or lack thereof, as expressed by residents, in the latter case it is the role of the development in residents' lives. The third element of relationships with the territory is residents' involvement as measured by their interest in development affairs and their willingness to actively participate in resolving communal problems.

These three components shape the overall attitude of the development's community towards the sector of space they occupy. Kotus (2007) identifies:

- testimonies of negation,

- testimonies of neutrality,

- testimonies of belonging.

Testimonies of negation signify negative opinions of the inhabited territory and aversion towards it, which is linked to the residents" lack of a sense of belonging to the housing development. In the case of residents who did not express clearly negative or positive opinion of the inhabited space we may speak of testimonies of neutrality.

Positive attitudes towards the housing development and stronger emotional ties to it, as well as an active stance towards the development's affairs, were potential bases for the identification of testimonies of belonging.

In order to quantify the strength of residents' relationship the territory, a survey study was carried out ${ }^{1}$. The obtained results were used to measure collective feelings of attachment on a scale of 1-5, based on the percentage of positive answers, as presented in table 1.

\footnotetext{
${ }^{1}$ Sample sizes: Bernardyńska development $n=110$, Idzikowskiego development $n=239$, Sadyba development $n=187$, Stegny Południe development $n=175$.
} 
Table 1. Evaluations of relationship with territory based on respondents' statements

\begin{tabular}{|c|l|}
\hline \% of positive responses & Evaluation of relationship with territory \\
\hline $80-100$ & 5 - very strong relationship \\
\hline $60-79$ & 4 - strong relationship \\
\hline $40-59$ & 3 - average relationship \\
\hline $20-39$ & 2 - weak relationship \\
\hline $0-19$ & 1 - very weak relationship \\
\hline
\end{tabular}

Source: author's elaboration

\section{STUDY AREA}

The study was carried out in 2008 among the residents of 4 residential housing developments (prefabricated construction method) in Warsaw. The selected developments were: Stegny Południe, Sadyba, Bernardyńska, and Idzikowskiego. These developments are all situated within one neighbourhood (Mokotów) and managed by one housing cooperative (MSM Energetyka). However, they exhibit a variety of spatial planning characteristics (building layout, green spaces, recreational grounds). These characteristics are presented in table 2 .

Table 2. Selected spatial planning elements of residential housing developments

\begin{tabular}{|l|l|l|l|c|}
\hline & \multicolumn{1}{|c|}{$\begin{array}{c}\text { Building } \\
\text { layout }\end{array}$} & Buildings & Housing development space & $\begin{array}{c}\text { Number of } \\
\text { stairwells } \\
\text { per block }\end{array}$ \\
\hline Bernardyńska & nested & 13-storey & $\begin{array}{l}\text { Lack of numerical data. } \\
\text { Observations confirm a large } \\
\text { proportion of open space and } \\
\text { very small proportion of green } \\
\text { spaces }\end{array}$ & 8 \\
\hline Idzikowskiego & meandering & 3-storey & $\begin{array}{l}\text { green spaces - 76\% of total } \\
\text { housing development area }\end{array}$ & 16 \\
\hline Sadyba & block & 4 -storey & $\begin{array}{l}\text { open spaces - 82\% of total } \\
\text { housing development area } \\
\text { green spaces - 73\% of total } \\
\text { housing development area }\end{array}$ & 44 \\
\hline Stegny Południe & linear & 4-storey & $\begin{array}{l}\text { open spaces }-62 \% \text { of total } \\
\text { housing development area } \\
\text { green spaces }-37 \% \text { of total } \\
\text { housing development area }\end{array}$ & 28 \\
\hline
\end{tabular}

Source: author's elaboration

Spatial planning characteristics may be classified according to their "agreeability" for residents, as shown in table 3. 
Table 3. Initial assessment of housing developments' selected spatial planning elements

\begin{tabular}{|l|c|c|c|c|c|}
\hline & $\begin{array}{c}\text { Building } \\
\text { layout }\end{array}$ & $\begin{array}{c}\text { Open and gre- } \\
\text { en spaces }\end{array}$ & $\begin{array}{c}\text { Recreational } \\
\text { grounds }\end{array}$ & $\begin{array}{c}\text { Building } \\
\text { height }\end{array}$ & Grade \\
\hline Bernardyńska & 1 & 1 & 1 & 1 & 1 \\
\hline Idzikowskiego & 4 & 4 & 4 & 4 & 4 \\
\hline Sadyba & 3 & 3 & 3 & 2,5 & 2,875 \\
\hline Stegny Południe & 2 & 2 & 2 & 2,5 & 2,125 \\
\hline
\end{tabular}

Source: author's elaboration

The most "agreeable" housing development (based on spatial characteristics) is Idzikowskiego. The development has a meandering building layout, due to which the development's open space is enclosed within development boundaries, and is endowed with the best-planned green spaces (it represents a high proportion of the developments' open space and is of high quality). Residents have various amenities at their disposal, such as benches, recreational areas that accommodate various age groups, team sports playing fields, and table tennis facilities. A positive evaluation was accorded also to the developments' relatively low number of stairwells and low building height (3 storeys).

The Bernardyńska development fell on the opposite end of the spectrum. Although it is small, its spatial characteristics cannot be evaluated positively. The development is composed of eight 13-storey buildings, in a nested layout, which precludes the creation of internal open spaces for residents. The buildings are situated along one street, which brings residents into close contact with road traffic and facilitates the transit of non-residents through the development, whose open space is mostly concrete, with only sparse lawns and individual trees to count as green spaces. Residents do not benefit from any adjacent recreational areas and the only amenities at their disposal are benches.

The other two housing developments included in the study occupy an intermediate position between the Idzikowskiego and Bernardyńska developments. Sadyba's building layout resembles that of Idzikowskiego (block), has a high proportion of green spaces, and its open space is well equipped with adjacent recreational facilities. Stegny Południe's building layout is linear ${ }^{2}$, which creates long corridors open on two sides, resulting in a lack of a clearly defined internal space within the development. Despite the relatively high proportion of open spaces, Stegny Południe does not have many green spaces, which are limited to lawns and individual trees.

\footnotetext{
${ }^{2}$ A portion of the Stegny Południe development's buildings are distributed according to the nested layout; the study was carried out among residents of the part where the building layout is linear;
} 


\section{HOUSING DEVELOPMENT EVALUATION}

The study measured resident's opinions of distinct spatial planning elements and of the housing developments overall.

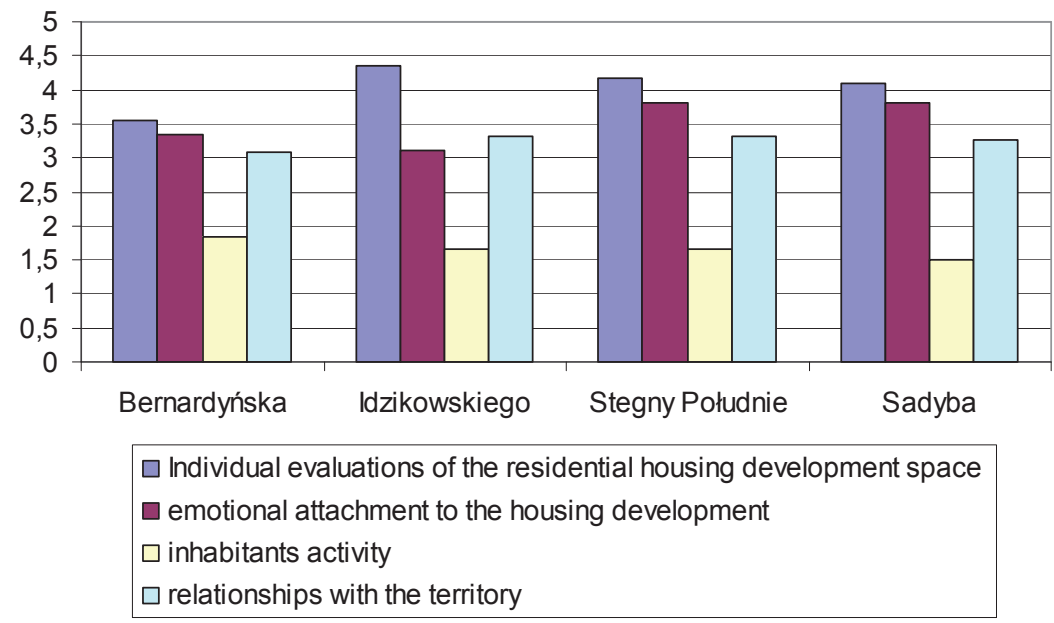

Fig. 1. Evaluation of residents' relationship with the territory Source: author's elaboration

The highest grade given to a development by its own residents was received by Idzikowskiego - grade 3,8 - while Bernardyńska and Sadyba were rated lowest by their residents - grade 3 (Fig. 1). Residents of Idzikowskiego gave the most frequently positive evaluations of the adjacent green spaces (considering it well-kempt and aesthetically pleasing) and recreational grounds; they enjoy the development's open spaces. The residents of all 4 developments evaluated negatively the amount of available green space, considering it insufficient, but here too the residents of Idzikowskiego responded least negatively. By far the best evaluation of development size was recorded by the residents of Idzikowskiego (grade 5) - the residents of the remaining developments evaluated this spatial attribute of their developments significantly less positively.

While the high marks given to Idzikowskiego were unsurprising (in initial assessments, this developments space also received highest marks), unexpectedly high marks (only slightly lower than for Idzikowskiego) were given to Stegny Południe, which, based on its building layout and other spatial planning elements, was not positively evaluated in initial assessments. It is likely that the residents of Stegny Południe are "content with what they have", notwithstanding the fact that their living conditions are not among the most comfortable (their declared feelings of emotional attachment to the development were the strongest recorded). 


\section{EMOTIONAL ATTACHMENT TO THE HOUSING DEVELOPMENT}

Emotional attachment to the housing development was evaluated based on the development's role in residents' lives, their satisfaction with their living space, unwillingness to move elsewhere, and respondents' stated emotional attachment.

The emotional component of residents' relationships with the housing developments may be characterised as strong in all 4 cases (the average value in each case was 3,75 ). It is worthwhile to examine the various elements of these relationships. In all cases, the development's role as a space of contact with other residents was evaluated (grade 2), as was the residents' level of satisfaction with their residential space (grade 5). Stegny Południe residents more frequently declared a "rootedness" and an attachment to the development (grade 5, in the other developments - 4). In the case of Idzikowskiego the open spaces least frequently serve to spend free time (grade 2, in the other developments - 3). Stegny Południe residents declared stronger emotional attachments to the housing development, yet were less frequent in declaring an unwillingness to move elsewhere - this may be due to a need to improve living conditions, notwithstanding their positive evaluation by residents.

Among the determinants of emotional attachment are undoubtedly such social attributes as the length of residency in the housing development. The longest residency periods were declared by Sadyba residents (27 years) - the shortest by residents of Idzikowskiego (14 years). As demonstrated by the study, the length of residency does not on its own account for the emotional attachment of residents: residents of Sadyba were evaluated to have the same level of attachment as those of Bernardyńska and Idzikowskiego, despite having the longest residency histories. The average number of residency years in the Bernardyńska development equals 20 lat, in Idzikowskiego - 14 years, in Sadyba - 27 years, in Stegny Południe - 22 years. The number of residency years in Idzikowskiego differs significantly from the averages in the other developments (statistical significance $<0,0001$ ). In the case of the Stegny Południe and Bernardyńska developments, the average length of residence does not differ statistically - however, the residents of the two developments are characterised by differing levels of emotional attachment.

In all 4 housing developments the most frequently cited reason for not wanting to move elsewhere is the residents' emotional attachment to their housing development (Fig. 2). This characteristic was most frequently noted in the case of the Bernardyńska and Sadyba developments. In the other developments, other important factors were the housing developments' internal characteristics, such as good planning and management. 


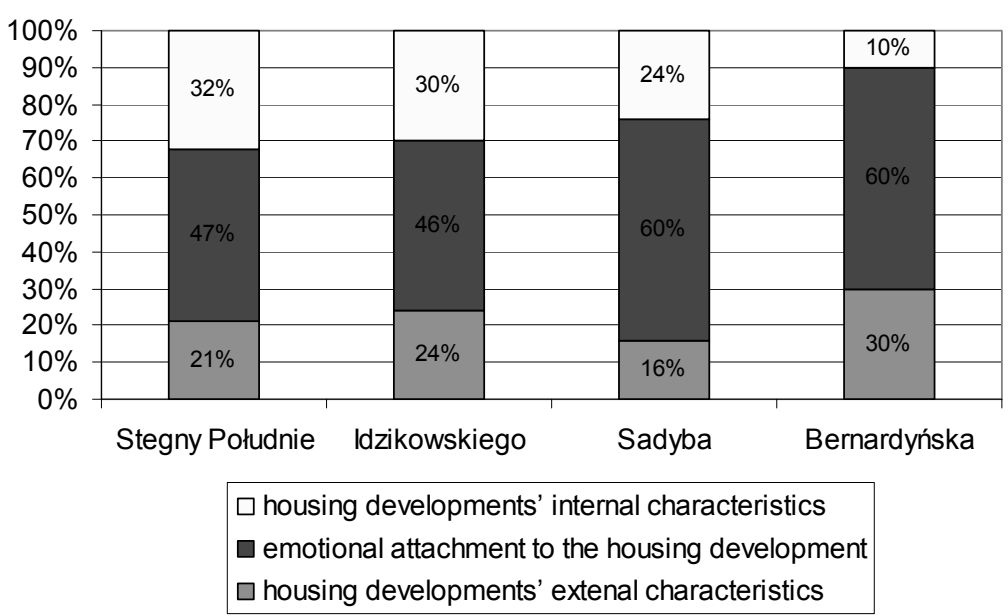

Fig. 2. Residents' unwillingness to move elsewhere - reasons Source: author's elaboration

\section{RESIDENTS' INVOLVEMENT}

In all 4 housing developments residents exhibit a low level of „local” involvement. In this aspect, the relationships with the territory must be qualified as weak.

Differences between developments are small, but the highest score was attained by Bernardyńska (Fig. 1). Residents there more frequently declared a willingness to participate in residents' meetings but, just as was the case with the other developments, they were not willing to undertake more ,active” involvement, such as organising meetings, collecting signatures, or reporting problems to the development's administration or to the police. As well, only a small number of residents declared a willingness to participate in group activities. It is possible that Bernardyńska residents' ranking in this study as the most active is the result of the development's comparatively small size. Housing development size may be one of the deciding factors for resident involvement as it may contribute to a feeling of belonging to a spatially separate small community. Another determinant of local involvement may be the residents' own characteristics, including their level of education. Nearly $75 \%$ of Bernardyńska residents reported having higher education, while the proportion was nearer to $50 \%$ in the other developments.

\section{CONCLUSIONS}

Relationships with the territory as measured by the resident's positive evaluation of their housing development were strong in the case of the 
Idzikowskiego and Stegny Południe developments and weaker for Bernardyńska and Sadyba. It is clearly evident that in Sadyba and Stegny Południe residents' opinions did not corroborate initial assessments of the developments' spatial attributes. Resident's opinions proved more positive in the case Stegny Poludnie, which has a linear building layout and a low proportion of recreational grounds and green spaces; they were more negative, however, in Sadyba, which was initially assessed as being more "agreeable" for residents than Stegny Południe. Better spatial conditions are not always reflected by residents' positive opinions.

Strong relationships with the territory were observed in all the housing developments. It may be said that emotional attachment to the housing development forms independently of its physical characteristics. Once developed, however, the attachment prompts a tendency towards positive evaluations of the space.

The residents of all 4 housing developments exhibited weak and very weak relationships with the territory when it was measured by their level of "local" involvement. This was most evident in the case of Sadyba residents. Although they declare a strong emotional attachment to the development and despite agreeable spatial conditions, Sadyba residents exhibit neither a willingness to be actively involved, nor an interest in the housing development's affairs.

In short, residents' relationships with the territory may be described as average, but somewhat stronger in two of the housing developments Idzikowskiego and Stegny Południe. Applying a classification of testimonies related to the territory, the residents of the studied residential housing developments provided accounts of partial belonging. Their accounts contain very strong cognitive and emotional components, but a very weak behavioural component.

\section{REFERENCES}

Kotus J., 2007, Natura wielkomiejskich sqsiedztw. Analiza subsqsiedzkich i sqsiedzkich terytorialnych podsystemów spotecznych $w$ Poznaniu, [The nature of metropolitan neighbourhoods. An analysis of sub-neighbourhood and neighbourhood territorial social subsystems in Poznan], Wydawnictwo Naukowe UAM, Poznań.

Misiak W., 1993, Jakość życia $w$ osiedlach miejskich, [The quality of life in urban housing developments], Wydawnictwo Uniwersytetu Wrocławskiego, Wrocław 